\title{
HEALTH STATUS, NUTRITION, AND FRAGILE STATES ${ }^{2}$
}

Keywords: health status, goverment, nutrition, fragile states

\begin{abstract}
Fragile states have several key characteristics: (1) uncertain control of territory and/or not having full control of legitimate use of force; (2) decline in legitimacy of collective and authoritative government decisions; (3) difficulties with providing public goods and services; (4) problems with interacting with other states as a member of the larger international community. Data on The Fund for Peace's Fragile State Index from 2016 are used to measure the dependent variable. The independent variables of interest are health and nutrition, to determine if these factors-as influences on citizens' behavior-would have anything to do with fragility. This paper, then, explores the role of two biosocial variables in affecting degree of fragility. Results are discussed as well as implications.
\end{abstract}

\section{INTRODUCTION}

Fragile states call for much attention. The Fund for Peace defines the concept as containing several attributes, among the most common of which are: a state's loss of physical control over its territory or its monopoly on the legitimate use of force; the erosion of legitimate authority to make collective decisions; an inability to provide reasonable public ser-

1 Penn State Harrisburg, Sap12@psu.edu

2 Original document prepared for delivery at Northeastern Political Science Association, Philadelphia, November 9-11, 2017. 
vices; the inability to work with other states as full members of the international community (Fund for Peace, 2017a). Such fragile states can create a seedbed for international unrest and conflict. Others have also developed concepts and methods for identifying fragile states (e.g., Marshall, 2008; USAID, 2006; World Bank, 2010; OECD, 2016; Baker, 2017).

The Fund for Peace Fragile States Index (FSI) is designed not only to highlight the normal pressures that all states experience, but also to identify when those pressures outweigh states' capacity to manage those pressures (Fund for Peace, 2017a). One common theme among the various publications noted above is the desire to use the metrics for identifying the level of fragility in order to facilitate interventions to address that. Data can be used as "early warnings" of potential problems that can affect other nations if not addressed.

Development of indices of fragility can be useful in a number of ways. One, such metrics can be used to assess which states are in greater jeopardy. To illustrate: with 2016 data, the following states had the highest fragility scores in descending order - Somalia (the most fragile state), South Sudan, Central African Republic, Sudan, Yemen, Syria, Chad, Congo, Afghanistan, Haiti, Iraq. At the other end of the continuum (from least fragile on): Finland, Norway, New Zealand, Denmark, Switzerland, Australia, Ireland, Sweden, Iceland, and Canada (Fund for Peace 2017a). A second goal is to identify changes in fragility with individual countries over time. For example, the Fund for Peace's FSI is delineated from 2007 through 2016 for most countries. This allows for tracking measures over time to assess improvements - or increasing fragility. This can indicate if interventions have improved a state's level of fragility. For instance, between 2007 and 2016, the following states showed the greatest improvement, becoming less fragile: Moldava, Cuba, Turkmenistan, Belarus, Seychelles, and Barbados. On the other hand, states labelled "Critical worsening" include: Senegal, Yemen, Mali, Syria, and Libya.

Many substantive issues have been addressed in the literature, showing the value of investigating state fragility. Among these: the effects of aid allocation to fragile states (Manor, 2007; Carment, Samy, and Prest, 2008; Osaghae, 2007; Baliamoune-Lutz, 2009; Gisselquist, 2014), social cohesion and state/nation building (Kaplan, 2009; Grotenhuis, 2016), institution 
building (Gisselquist, 2014), health systems (Haar, 2012), and violence and civil war (Taylor, n.d.; Brown and Langer, 2013; Fearon, 2010).

This paper, though, explores the effects of a variety of predictors on fragility of states. Past research has suggested the possibility that two biosocial variables might be associated with extent of fragility - health status and nutrition. In analysis using Freedom House data on democracy from 2014 (Puddington, 2014) and the Fund for Peace FSI , the Pearson's coefficient was .717, indicating that the more democratic a state is, the less fragile it is. That simple correlation suggests that the logic for health status and nutrition to affect level of democracy might be implicated in extent of fragility.

An earlier paper explores two related biological elements that might affect the extent of democratization across countries - nutrition level and health status. Cross-national data indicate that health status - but not nutrition - has an independent effect associated with higher levels of democracy (Peterson with Franzese-Peterson, 2015). On the face of it, this may not seem intuitively obvious. But there is a literature that suggests - directly or indirectly - that these variables may be additional factors to take into account in the process of democratization. In this endeavor, the issue of the relevance of biology for the study of politics is addressed (on this more general usage, see, e.g., Blank et al, 2014; Peterson and Somit, 2017).

Only a miniscule set of studies directly focus on the effect of health or nutrition on democracy itself. Perhaps the most direct example is the research reported by Barro (1996). He found that one measure of health (infant mortality rate) was associated with depressed odds of democracy (using Freedom House scores). According to Stauffer (1969), malnutrition, parasitic disease, and the like undermine a country's ability to achieve the mobilization regarded as a precondition for national development.

Other studies suggest indirect pathways by which health and nutrition might affect Democracy (for an early reflection on this, see Davies, 1963). Nutrition and health may affect a citizenry's political attitudes and behaviors in ways that affect democracy. One well established principle in the study of democracy is that those who do not participate have less voice in the policy process (e.g., Schlozman, Verba, and Brady, 2012; Verba and Nie, 
1972; Verba, Schlozman, and Brady, 1995). Research clearly indicates that there are class-based differences here, leading to those lower in socioeconomic status having less voice in political discussion - and, hence, less influence (e.g., see Schattschneider, 1960; Schlozman and Verba, 1979; Schlozman, Verba and Brady, 2012). Such factors influencing political participation rates by group of citizens can surely affect democracy when subtle (or not so subtle) biases leave certain groups less likely to mobilize and be heard.

More to the point for this paper? Evidence suggests that those with poorer nutrition and poorer health are more apt to participate less. On nutrition, data from India and the United States suggest that shortfalls in nutrition can reduce levels of political involvement, although the effects are not dramatic (e.g., Bhaskaran, 1982; Peterson, 1987, 1989). Other research has discovered that health status can affect political involvement and participation. Data from the United States, Sweden, Ireland, and many other countries suggest a statistical linkage between better health status and more political activity. (Booth and Welch, 1976; Peterson, 1987; Peterson and Somit, 1992; Schwartz et a1, 1975; Schwartz, 1978; Rahn and Gollust, 2013; Denny and Doyle, 2007; Brody and Sniderman, 1977; Mattilla et al., 2013; Pacheco and Fletcher, 2015; Soderlund and Repeli, 2014). Thus, research in the aggregate suggests (a) a direct association between health and nutrition and democracy, albeit based only on a very small number of studies and (b) an indirect association between health and nutrition and democracy via those variables' effects on participatory behavior and attitudes that are critical for a healthy democracy. Poorer nutrition and health status would reduce the voice of a segment of the population afflicted with such problems and, hence, render a society less democratic.

Based on the logic from the effects of nutrition and health status on democracy as summarized in the preceding survey of literature, we would hypothesize the following:

H1: Countries with lower levels of citizen nutrition will be more likely to be fragile.

H2: Countries with lower levels of citizen health will be more likely to be fragile. 
To assess these hypotheses, we would need to control for other factors. And what other variables might be included? Again, using analogy with the correlates of democracy literature. The following control variables were selected. Among these: education level, economic development, urbanization, and communication networks. Each would seem to have relevance for predicting extent of fragility. A brief discussion about each: A long line of studiesdating back over fifty years-has suggested a number of key factors. One of those is education level. A number of classic studies have suggested that years of education and literacy are within a country are associated with greater probability of democratization (e.g., Deutsch, 1961; McCrone and Cnudde, 1967; Banks, 1972; Vanhanen, 1984). Just so, this variable should affect fragility.

Another well documented set of variables linked to democratization is economic development and some degree of economic equality. Wealth per capita is also associated with democracy (e.g., using energy as a surrogate, see Burkhart and Lewis-Beck, 1994). Income equality can work toward democracy, and inequality undermine that (e.g., Muller, 1988; Muller and Seligson, 1994; Vanhanen, 1984, 2003).

Urbanization is another predictor found to be associated with democratization (e.g., see Cutright, 1963; McCrone and Cnudde, 1967; Banks, 1972; Vanhanen, 1984). Communication networks, too, appear to be related to democratization (e.g., see Deutsch, 1961; Neubauer, 1967; Lipset, 1963; Dutton, 2009). Other variables could be discussed as well, but-for the sake of parsimony-these are the key ones that we consider.

\section{RESEARCH METHODS}

\section{VARIABLES}

There are several different sources for the data to measure key variables. Nutrition and Health as predictor variables come from the 2014 Social Progress Index (Porter and Stern, 2014). The index of fragility comes from the Fund for Peace annual report (2017b). A number of variables come from the CIA Factbook (Central Intelligence Agency, 2014). Only those 
states with a population of $1,000,000$ or more are considered in statistical analysis below.

\section{DEPENDENT VARIABLE: FRAGILE STATES INDEX}

Data for construction of the FSI include content analysis of global media data to determine level of salience issues for the variety of "subindicators" in each country. Included in this analysis were media articles, research reports, and other information collected from well over 10,000 English language sources covering all countries in the world. A second source of information were quantitative data from many agencies that gather statistical information (e.g., the UN, World Bank, and so on). Finally, qualitative data. Social science researchers used their judgments to assess key events in the year being studies. The three different data branches were then pulled together to create an integrated data base for each country ( $\mathrm{N}=178$ countries).

The data base includes several indicators plus sub-indicators within each. It is tedious to present these, but it is necessary to understand the data base. The first indicator is cohesion. The first sub-indicator is the security apparatus. Is there a government monopoly on the use of force or are there other groups with military power? Is there a positive relationship between security and citizens? Is force used appropriately by government (or is there violence against the people by security forces?)? Is the presence of arms for many people a problem? A second sub-indicator is factionalized elites. Is there fragmentation by class, race, religion, and so on? Can ruling elites work together or is there gridlock? Then, group grievances. Are there divisions and schisms among different groups in society? Is there an historical component to these schisms? Are certain groups separated out by government for negative treatment? Is there "hate radio" and other media aligned against certain groups in society?

A second indicator is economic. One sub-indicator here is economic decline and poverty. Is there economic decline and considerable poverty? Is public debt excessive? Is there economic diversification? A second subindicator is uneven development. Is there considerable inequality in the state? Are there widespread perceptions among citizens of inequality? Are 
there routes to economic opportunity for people? Third, human flight and brain drain. Are people with technical and other expertise leaving the country? Is there an increase of citizens moving abroad (e.g., a diaspora)?

The third indicator is political. Sub-indicators include state legitimacy. This is constituted of such measures as confidence in the political process and political opposition (demonstrations and riots, for instance), which suggest problems. The term "transparency" is also included, but this appears to be an index of corruption. Openness and fairness of the political process is an additional sub-indicator. Then, extent of political violence. Finally, evidence of support for human rights and the rule of law. For human rights, is there evidence for provision of health care, education, shelter, and infrastructure?

A fourth indicator is social. One sub-indicator is demographic pressure. Indicators include population pressure, public health, food and nutrition, environment, and access to resources. A second sub-indicator is orientation to refugees and internally displaced people. Are there safe conditions for refugees? Are there adequate resources? What is the extent of internally displaced persons? Are there adequate resources for such individuals?

The final indicator is external intervention. Are there interventions in the country's economy, politics, or are foreign military or police forces "in country"?

In this essay, the dependent variable is a sum of all indicators above. The least fragile score a state could receive is 10; the worst score (extremely fragile) is 120 .

\section{INDEPENDENT VARIABLES}

The CIA World Handbook, 2014 is the source for the following metrics:

a) Population (needed to norm one key variable, as per g);

b) School life expectancy (educational attainment in terms of average number of years of education attained);

c) GDP per capita;

d) Urbanization (percentage of population living in urban areas);

e) number of cell phones in use; 
f) Number of internet users (For the relevance to democracy, see Dutton, 2009);

g) An index of communications (the variable used in analysis: number of cell phones plus number of internet users divided by population).

Porter and Stern with Green, Social Progress Index 2014

a) Nutrition and Basic Health Care Index. This is composed of measures of the following: Undernourishment, depth of food deficit, maternal mortality rate, stillborn rate, child mortality rate, deaths from infectious diseases.

b) Health and Wellness Index. This index includes metrics made up of the following: life expectancy, non-communicable diseases deaths between 30 and 70 years of age; obesity rates; deaths because of outdoor air pollution; suicide rate.

\section{DATA ANALYSIS}

The first order of business is to describe the basic correlation structure among the variables described above. Table 1 provides results.

Table 1. Correlates of the Fragility Index $(\mathrm{N}=122)$

\begin{tabular}{|l|l|l|l|l|l|l|l|}
\hline & Fragility & GDP & $\begin{array}{c}\text { Nutri- } \\
\text { tion }\end{array}$ & Health & Urban & $\begin{array}{c}\text { Educa- } \\
\text { tion }\end{array}$ & $\begin{array}{c}\text { Communi- } \\
\text { cation }\end{array}$ \\
\hline Fragility & --- & & & & & & \\
\hline GDP & -.856 & --- & & & & & \\
\hline Nutrition & -.743 & .678 & --- & & & & \\
\hline Health & -.410 & .431 & .262 & --- & & & \\
\hline Urban & -.671 & .712 & .743 & .286 & --- & & \\
\hline Education & -.832 & .759 & .795 & .261 & .727 & --- & \\
\hline Communication & -.803 & .796 & .812 & .239 & .741 & .740 & --- \\
\hline
\end{tabular}

All correlations significant at $<.001$ level

For the dependent variable, the fragility index, we see that all predictor variables are statistically significantly associated with the index. All coef- 
ficients are significant at $<.001$. Strongest correlates, in descending order, are GDP per capita, years of education, communications, nutrition, percentage urban, and health status. The high correlations among some of the independent variables, of course, raise the possibility of multicollinearity in regression analysis. That issue will be tracked closely in subsequent analysis.

Table 2 is the baseline for additional analysis. Here, the effects of nutrition and health status on fragility (controlling other independent variables) are assessed.

Table 2. Multiple Regression (Unstandardized regression coefficients and standard errors): Predicting Fragility $(\mathrm{N}=124)$

\begin{tabular}{|c|c|c|c|c|}
\hline Variable & Model 1 a & Model $1 \mathrm{~b}$ & Model 2 a & Model 2 b \\
\hline GDP & & $-.505(.146)^{\star \star \star}$ & & $-.453(, 093)^{\star \star \star}$ \\
\hline Nutrition & $-1.157(.091)^{* * *}$ & $-.020(.126)$ & & \\
\hline Health & & & $-1.031(, 214)^{\star * \star}$ & $-.230(.121)^{\star}$ \\
\hline Urban & & $.145(.069)^{\star}$ & & $.132(.066)^{\star}$ \\
\hline Education & & $-3.025(.552)^{* * *}$ & & $-2.968(.487)^{\star * *}$ \\
\hline Communication & & $-12.933(3.321)^{\star \star \star}$ & & $-14.030(2.945)^{\star * \star}$ \\
\hline Multiple R & .747 & .887 & .391 & .890 \\
\hline $\begin{array}{l}\text { Adjusted R } \\
\text { Squared }\end{array}$ & .559 & .778 & .146 & .784 \\
\hline $\mathrm{P}$ & .000 & .000 & .000 & .000 \\
\hline $\begin{array}{l}\text { Standard } \\
\text { Error }\end{array}$ & 16.36069 & 11.35741 & 22.38982 & 11.19253 \\
\hline
\end{tabular}

${ }^{*}>05 ;{ }^{* *}>.01 ;{ }^{* * *}>.001$

Nutrition as a sole predictor is strongly associated with fragility $(\mathrm{P}<.001)$ in Model 1a. The greater the nutrition level within a state, the less the fragility. Note: the coefficient of -1.157 is negative because higher scores speak to higher levels of nutrition and lower scores for fragility testify to less fragility. Thus, a first cut suggests that nutrition may well be a strong factor affecting fragility.

When the effects of GDP per capita, percentage population living in urban areas, education level, and communication networks are taken into 
account, the effect of nutrition essentially disappears. The unstandardized regression coefficient is -.020-much less than the standard error. The end result is a nonsignificant association with fragility. Overall, the model has a multiple $\mathrm{R}$ of .887, an adjusted $\mathrm{R}$ squared of .778, and a highly significant P. In that sense, a successful model even without an effect by nutrition. The central point, of course, is that nutrition does not have an effect in this model.

Model 2a shows the relationship between health status and fragility. The unstandardized coefficient is well over twice the size of the standard error $(\mathrm{P}<.001)$. However, the effect of health on fragility can only be properly understood by taking into account the other independent variables (Model 2b depicts this).

Three predictors are significant at the .001 level-GDP, education, and communication networks. Urbanization is significant at the .05 level (although not in the direction predicted). Health status? It, too, is significant at the .05 level. Thus, even with controls in place, this variable has an association with fragility. The model, overall, is solid. Multiple $\mathrm{R}=.890$; adjusted $\mathrm{R}$ squared $=.784 ; \mathrm{P}<.001$.

One additional test seems relevant-a regression analysis with both nutrition and health in the equation. Table 3 addresses this.

Table 3. Multiple Regression (Unstandardized regression coefficients and standard errors): Predicting Fragility $(\mathrm{N}=124)$

\begin{tabular}{|l|l|}
\hline \multicolumn{1}{|c|}{ Variable } & \multicolumn{1}{c|}{ Model 3 } \\
\hline GDP & $-.645(.132)^{\star * \star}$ \\
\hline Nutrition & $-.053(.118)$ \\
\hline Health & $-.370(.140)^{* \star}$ \\
\hline Urban & $.136(.066)^{\star}$ \\
\hline Education & $-3.116(, 563)^{* * *}$ \\
\hline Communication & $-10.137(3.305)^{\star *}$ \\
\hline Multiple R & .916 \\
\hline Adjusted R Squared & .830 \\
\hline P & .000 \\
\hline Standard Error & 10.02942 \\
\hline
\end{tabular}

${ }^{*}>.05 ;{ }^{* *}>.01 ;{ }^{* * *}>.001$ 
The central observation: nutrition still remains a very weak predictor (not significant), whereas health status is significant at $\mathrm{P}<.01$. Otherwise, results are quite similar for Models $1 \mathrm{~b}$ and $2 \mathrm{~b}$. In short, one biosocial variable remains a factor in explaining the variation in fragility.

The final statistical analysis is a stepwise regression run (Table 4), once more including both nutrition and health status as independent variables. This approach is used to determine the most parsimonious model using the variables previously described. As before, the first three variables entering the equation are GDP. Education level, and communication networks. Next to enter is health status (significant at $\mathrm{P}<.01$ ). Nutrition does not enter the equation.

Table 4. Stepwise Multiple Regression (Unstandardized regression coefficients and standard errors): Predicting Fragility (N=124)

\begin{tabular}{|l|l|}
\hline \multicolumn{1}{|c|}{ Variable } & \multicolumn{1}{c|}{ Model 4 } \\
\hline GDP & $-.633(.128)^{* * *}$ \\
\hline Education & $-3.230(, 501)^{* * *}$ \\
\hline Communication & $-10.899(2.823)^{* * *}$ \\
\hline Health & $-.378(.138)^{* *}$ \\
\hline Urban & $.130(.064)^{*}$ \\
\hline Nutrition & --- \\
\hline Multiple R & .916 \\
\hline Adjusted R Squared & .839 \\
\hline P & .000 \\
\hline $\begin{array}{l}\text { Standard } \\
\text { Error }\end{array}$ & 9.99508 \\
\hline
\end{tabular}

${ }^{*}>.05 ;{ }^{* *}>.01 ; * * *>001$

The variables entering the equation produce a Multiple R of .916, Multiple $\mathrm{R}$ Squared $=.839 ; \mathrm{P}<.001$. The standard error is 9.99508 . One lingering question raised earlier is the correlation matrix (Table 1) which displays a number of correlation coefficients that are very high. This suggests the possibility of multicollinearity in the multivariate analyses. However, diagnostics do not indicate serious evidence of this in the equations. 


\section{DISCUSSION}

The focus of this paper is somewhat different from other analyses of fragile states. Here, the goal is to ascertain if certain biosocial variables might affect the odds of a country being deemed fragile. This is part of a larger ongoing study to explore the extent to which such variables affect various attributes of countries-extent of democracy and electoral integrity (Peterson, 2017) and, here, fragility. Biosocial variables are not routinely examined as factors affecting individual or international political phenomena (for summaries of such linkages, see Peterson and Somit, 2017).

In terms of that goal, this paper suggests that nutrition does not have much role in affecting fragility. However, health status appears to be involved in the process by which a country becomes fragile. This in itself is a finding that indicates that biosocial factors can have a role in comparative and international politics.

What of future research? To the extent that the approach undertaken here has some value, this line of work can be extended to other phenomena pitched at the global level - and of course, at the individual level. There is already a considerable literature linking biology and politics, and this paper is part of a larger attempt to study empirically the extent to which biology affects politics and political action.

\section{BIBLIOGRAPHY:}

Baker, Pauline H. (2017). Reframing Fragility and Resilience, Washington, DC, Creative Associates International.

Baliamoune-Lutz, Mina. (2009). Institutions, trade, and social cohesion in fragile states. Journal of Policy Modeling, 31, 877-890.

Banks, Arthur S. (1972). Correlates of democratic performance. Comparative Politics 4: 217- 230.

Barro, Robert J. (1996). Democracy and growth. Journal of Economic Growth, 1, 1- 27.

Barro, Robert J. (1996). Democracy and growth. Journal of Economic Growth, 1, 1-27.

Bhaskaran, S. (1982). Linkage between malnutrition and political apathy. Presented at International Political Science Association, Rio de Janeiro. 
Booth, Alan and Susan Welch. (1976). Stress, health, and political participation. Presented at International Political Science Association, Edinburgh, Scotland.

Brody, R.A. and P.M. Sniderman (1977). From life space to polling place. British Journal of Political Science, 7, 337-360.

Brown, Graham K. and Arnim Langer. (2012). Elgar Handbook of Civil War and Fragile States, Cheltenham, UK, Edward Elgar.

Burkhart, Ross E. and Michael S. Lewis-Beck. (1994). Comparative democracy: The economic development thesis. American Political Science Review, 88, 903-910.

Carment, David, Yiagedeesen Sami, and Stewart Prest. (2008). State fragility and implications for aid allocation. Conflict Management and Peace Science, 25, 349-373.

Central Intelligence Agency (2013). The CIA World Factbook 2014, New York, Skyhorse Publishing Inc.

Cutright, Philips. (1963). National political development: Measurement and analysis. American Sociological Review, 28, 253-264.

Davies, James C. (1963). Human Nature in Politics, New York, John Wiley.

Denny, Kenny and Orla Doyle. (2007). Take up thy bed and vote: Measuring the relationship between voter behaviour and health. European Journal of Public Health, 17, 400401.

Deutsch, Karl W. (1961). Social mobilization and political development. American Political Science Review, 55, 493-514.

Dutton, William H. (2009). The fifth estate emerging through the network of networks. Prometheus, 27, 1-15.

Fearon, James D. (2010). Do governance indicators predict anything? The case of "fragile states" and civil war. Draft of paper prepared for delivery at the 2011 Annual Bank Conference on Development Economics.

Fund for Peace. 2017a. What does "state fragility" mean? fsi.fundforpeace.org/faq-06state- fragility.

Fund for Peace. 2017b. 2017 Fragile States Index, Washington, D.C., Fund for Peace.

Gisselquist, Rachel M. (2014). Aid and institution-building in fragile states. Annals DO I1:10.1177/00027116214546991.

Grotenhuis, Rene (2016). Nation-Building as Necessary Effort in Fragile States, Amsterdam, Amsterdam University Press.

Haar, Rohini J. (2012). Health and fragile and post-conflict states. Medicine, Conflict, and Survival, 28, 289-316.

Kaplan, Seth. (2009). Identity in fragile states: Social cohesion and state building. Development, 52, 466-472.

Lipset, Seymour Martin. (1963). Political Man, Garden City, NY, Anchor Books.

McCrone, Donald J. and Charles F. Cnudde. (1967). Toward a communication theory of democratic development. American Political Science Review, 61, 72-79. 
Manor, James (Ed.). (2007). Aid That Works: Successful Development in Fragile States, Portland, World bank.

Marshall, Monty G. (2008). Fragility, Instability, and the Failure of States: Assessing Sources of Systemic Risk, Council on Foreign Relations.

Mattilla, Mikko, Peter Soderlund, Hanna Wass, and Lauri Rapeli. (2013). Healthy voting: The effect of self-reported health on turnout in 30 countries. Electoral Studies, 32, 886- 891.

Muller, Edward N. (1988). Democracy, economic development, and economic inequality. American Sociological Review, 53, 50-68.

Muller Edward N. and Mitchell A. Seligson. (1994). Civic culture and democracy. American Political Science Review, 88, 635-662.

OECD. (2016). States of Fragility 2016: Understanding Violence, Paris, OECD Publishing. Osaghae, Eghosa E. (2007). Fragile states. Development in Practice, 17, 691-699.

Pacheco, Julianna and Jason Fletcher. (2015). Incorporating health into studies of political behavior: Evidence for turnout and partisanship. Political Research Quarterly, 68 (1), 104-116.

Peterson, Steven A. (1987). Biosocial predictors of older Americans' political behavior. Politics And the Life Sciences, 5, 246-251.

Peterson, Steven A. (1989). You are what you eat: nutritional status and political behavior among the elderly. Journal of Nutrition for the Elderly, 9, 51-66.

Peterson, Steven A. (1991). Health of the polity. Politics and the Life Sciences, 10, 65-68.

Peterson, Steven A. (2017). Health status and electoral integrity. Presented at Association for Politics and the Life Sciences meeting, Chicago.

Peterson, Steven A. with Evan Franzese-Peterson (in press). Health Status, Nutrition, and Democratization: A Comparative Study, Reality of Politics.

Peterson, Steven A. and Albert Somit (1992). Older women: Health and political behavior. Women \& Politics, 12, 87-108.

Peterson, Steven A. and Albert Somit (eds.) (2017). Handbook of Biology and Politics, Cheltanham, UK, Edward Elgar Publishing.

Porter, Michael E. and Scott Stern with Michael Green (2014). Social Progress Index 2014. Retrieved from: http://www.socialprogressimperative.org/system/resources/ W1siZiIsIjIwMTUvMDEvMDkvMjAvNTUvMTEvNzg4L1NvY2lhbF9Qcm9ncmVzc19JbmRleF8yMDE0X1JlcG9ydF9lXzJfLnBkZiJdXQ/Social\%20Progress\%20 Index\%202014\%20Report\%20e\%20\%20\%282\%29.pdf

Puddington, Arch (2014). Freedom in the World 2014. Retrieved from: https://freedomhouse.org/sites/default/files/Freedom\%20in\%20 ${ }^{\text {th }} \mathrm{e}$ 20World\%202014\% 20Booklet. pdf

Puddington, Arch and Tyler Roylance (2017), Freedom in the World 2017. 
Rahn, Wendy and Sarah Gollust. (2013). The bodies politic: Chronic health conditions and participatory inequalities. Presented at American Political Science Association, Chicago, IL, August 29-September 1.

Schattschneider, E.E. (1960). The Semisovereign People, New York, Holt, Rinehart, and Winston.

Schlozman, Kay Lehman and Sidney Verba. (1979). Injury to Insult, Cambridge, MA, Harvard University Press.

Schlozman, Kay Lehman, Sidney Verba, and Henry E. Brady. (2012). The Unheavenly Chorus: Unequal Political Voice and the Broken Promise of American Democracy, Princeton, Princeton University Press.

Schwartz, David C. (1978). Health status, self-image and political behavior in an American political elite. Presented at Western Political Science Association meeting, Los Angeles.

Schwartz, David C., J. Garrison, and J. Alouf. (1975). Health, body images, and political socialization. In David C. Schwartz and Sandra Kenyon Schwartz (Eds.), New Directions in Political Socialization, New York, The Free Press.

Soderland, Peter and Laurie Rapeli. (2014). In sickness and in health: Personal health and political participation in the Nordic countries, Politics and the Life Sciences, 34: 28-43.

Stauffer, Robert. (1969). The biopolitics of underdevelopment. Comparative Political Studies, 2, 361-387.

Taylor, Sebastian A.J. “Fragile and conflict affected states. Retrieved from: www.stabilityjournal.org/articles/10.5334/sta.dy

USAID. (2006). Fragile State Indicators: A Supplement to the Country Analytical Template. Retrieved from: http://pdf.usaid.gov/pdf_docs/Pnadg262.pdf

Vanhanen, Tatu. (1984). The Emergence of Democracy, Helsinki, The Finnish Society of Sciences and Letters.

Vanhanen, Tatu. (2003). Democratization: A Comparative Analysis of 170 Countries, London, Routledge.

Verba, Sidney and Norman Nie. (1972). Participation in America, New York, Harper and Row.

Verba, Sidney, Kay Lehman Schlozman, and Henry E. Brady. (1995). Voice and Inequality: Civic Voluntarism in American Politics, Cambridge, MA, Harvard University Press. World Bank. (2010). The World Bank's Country Policy and Institutional Assessment: An Evaluation, Washington, DC, The World Bank. 